\title{
Water use efficiency and yield responses of cotton to field capacity-based deficit irrigation in an extremely arid area of China
}

\author{
Haifeng $\mathrm{Li}^{1,2,3}$, Zhiming $\mathrm{Qi}^{1,3,4}$, Dongwei Gui ${ }^{1,3,4}$, Fanjiang Zeng ${ }^{1,3,4 *}$ \\ (1. State Key Laboratory of Desert and Oasis Ecology, Xinjiang Institute of Ecology and Geography, Chinese Academy of Sciences, Urumqi \\ 830011, China; 2. School of Environmental and Land Resource Management, Jiangxi Agricultural University, Nanchang 330045, China; \\ 3. Cele National Station of Observation \& Research for Desert-Grassland Ecosystem in Xinjiang, Cele 848300, Xinjiang, China; \\ 4. University of Chinese Academy of Sciences, Beijing 100049, China)
}

\begin{abstract}
The objectives of present investigation were to test the effects on water use efficiency (WUE) and cotton yield of implementing a range of deficit irrigation regimes triggered at specific fractions of root zone soil moisture, field capacity $\left(\theta_{\mathrm{fc}}\right)$ and different crop phenological stages. The study was conducted on southern oasis of the Taklamakan desert, China. The cotton crop's $W U E$ was quantified, as were leaf photosynthesis and yield. From a photosynthetic perspective, deficit irrigation resulted in $16.8 \%, 10.3 \%$ and $2.2 \%$ increases in leaf $W U E$ under $\theta_{\mathrm{fc}}$-based regulated deficit irrigation (T1, T2, and T3), compared to the control, respectively. Cotton yield and its components were significantly affected by irrigation depths $(p \leq 0.05)$. A relatively high seed yield $\left(0.65 \mathrm{~kg} / \mathrm{m}^{3}\right)$ and the highest $W U E$ were achieved, under T3 (70\% $\theta_{\mathrm{fc}}$ at seedling stage, $60 \% \theta_{\mathrm{fc}}$ at squaring, $50 \% \theta_{\mathrm{fc}}$ at full-bloom, $70 \% \theta_{\mathrm{fc}}$ at boll, $70 \% \theta_{\mathrm{fc}}$ at boll cracking stage), showing it to be the most effective and productive irrigation schedule tested. As the application of $\theta_{\mathrm{fc}}$-based deficit irrigation in surface-irrigated cotton fields showed great potential in saving water, maintaining a high $W U E$, and improving cotton seed yield, a management strategy consisting or irrigation thresholds of $70 \% \theta_{\mathrm{fc}}$ in the root zone at the seedling, boll and boll cracking stages, and of $60 \% \theta_{\mathrm{fc}}$ at the squaring stage, and $50 \% \theta_{\mathrm{fc}}$ at the full-bloom stage, would be recommended for this extremely arid region.

Keywords: regulated deficit irrigation, evapotranspiration, seed cotton yield, water use efficiency, Qira Oasis DOI: $10.25165 /$ j.ijabe.20191206.4571
\end{abstract}

Citation: Li H F, Qi Z M, Gui D W, Zeng F J. Water use efficiency and yield responses of cotton to field capacity-based deficit irrigation in an extremely arid area of China. Int J Agric \& Biol Eng, 2019; 12(6): 91-101.

\section{Introduction}

Given that water scarcity is the major bottleneck limiting sustainable agricultural development in northwest $\mathrm{China}^{[1,2]}$, especially in the region's extremely arid areas where precipitation is insufficient to meet crop water requirements ${ }^{[3]}$, irrigation is particularly critical for agricultural production ${ }^{[4,5]}$. Traditionally, the quantity and timing of irrigation, usually some form of surface irrigation (e.g. flood irrigation or furrow irrigation), has been based on local farmers' experience. However, most traditional irrigation schemes' water utilization efficiency (WUE) is very low, typically less than $50 \%{ }^{[6]}$. In the arid regions of northwest China where crop irrigation employs close to $90 \%$ of available water, such inefficiency only contributes further to local water scarcity ${ }^{[7,8]}$. Growing oasification and expansion of oasis farmlands in recent years ${ }^{[9]}$ have led to excessive exploitation of water resources ${ }^{[10]}$, resulting in serious conflicts in meeting the water needs of agricultural production, ecosystems, and human populations ${ }^{[11-14]}$.

Widely cultivated, cotton (Gossypium hirsutum L.) is one of the world's most important commercial crops ${ }^{[15,16]}$. Northwest China's Xinjiang Uyghur Autonomous Region provides ideal climatic

Received date: 2018-08-17 Accepted date: 2019-10-25

Biographies: Haifeng Li, Assistant Professor, research interests: plant physiology and soil ecology, soil and water conservation, Email: haifeng11984@jxau.edu.cn; Zhiming Qi, Professor, research interests: irrigation and drainage engineering, Email: qzhiming@ms.xjb.ac.cn; Dongwei Gui, Professor, research interests: oasis ecology, Email: guidwei@ms.xjb.ac.cn;

*Corresponding author: Fanjiang Zeng, Professor, research interests: plant physiology and ecology in arid area, soil and water conservation. Xinjiang Institute of Ecology and Geography, Chinese Academy of Sciences, Urumqi 830011, China. Tel: +86-991-7885442, Email: zengfj@ms.xjb.ac.cn. conditions for cotton production, including abundant radiation and heat resources ${ }^{[17]}$. This region's contribution rose from $40 \%$ of China's cotton production in 2007 to $50 \%$ in 2012 and $60.8 \%$ in $2017^{[18]}$. Being a drought and salt tolerant plant ${ }^{[19-21]}$, cotton can be successfully grown under conditions of adverse to extreme water scarcity ${ }^{[22]}$. Given rising yields and net profits per unit area over the last two decades, the area of irrigated cotton production has expanded rapidly ${ }^{[23-26]}$. However, this has exacerbated the negative consequences of over-abstraction of water resources in this region that already water-scarced ${ }^{[4,27]}$. Given farmer's confidence and reliance on traditional irrigation methods and their experience-based management of its quantity and timing, approximately $40 \%$ of fields in Xinjiang province receive flood irrigation ${ }^{[28]}$. This potentially results in substantial deep seepage losses and inefficient use of water resources. It is therefore critical to optimize the region's water resource use efficiency by improving the cotton production process in terms of $W U E^{[29]}$.

Various studies had confirmed that deficit irrigation could decrease luxury crop growth, minimize water use, with little or no decline in yield ${ }^{[30-32]}$. However, the poor transfer of relevant research findings to the region's farmers have left them unconvinced of the benefits of adopting improved irrigation technologies. Given its effectiveness in reducing soil surface evaporation as well as increasing cotton yield and $\operatorname{crop}^{[33-35]}$, drip irrigation has been practiced in the region for many years. However, it has failed to meet the needs of smallholders and poor farmers in Xinjiang's Tarim Basin. Faced with a scarcity of educational resources, most farmers lack the knowledge and skills that would allow them to improve their farms' water productivity ${ }^{[36]}$. Accordingly, traditional irrigation methods - fixed irrigation volumes across all phenological stages — remain local farmers' first choice ${ }^{[29]}$. 
However, crop require different amounts of water at different phenological stages. As maintaining the optimum moisture regime during different growth stages is critical to maximizing cotton seed yield from the region's increasingly limited water resources ${ }^{[31,37]}$, farmers will need to implement management practices that reduce irrigation and increase the efficiency of its use ${ }^{[38-40]}$. Such water-efficient irrigation methods are based on the root zone moisture deficit, with irrigation being triggered when soil moisture $(\theta)$ falls below a threshold fraction of $\theta_{\mathrm{fc}}$. The $\theta$ can be measured directly or an estimated change in crop root zone $\theta$ over time (e.g., between irrigation events) can be calculated through a simple water balance with given water inputs (i.e., irrigation, rainfall, previous soil $\theta$ ) and losses (i.e., crop evapotranspiration, deep percolation, and runoff $)^{[41]}$. A soil water balance method that estimates crop water use by multiplying a reference crop's evapotranspiration by a crop-specific coefficient has been practiced for decades and continues to be an acceptable method for irrigation scheduling ${ }^{[39]}$. In the arid Xinjiang region that presently facing the cotton production situation, implementing a $\theta_{\mathrm{fc}}$-based soil water balance irrigation management system could procure water savings and improve $W U E^{[39,41,42]}$.

Accordingly, a field experiment was conducted to test the effects of regulated deficit irrigation regimes on WUE and yield of cotton in an extremely arid region of China's Xinjiang Uyghur Autonomous Region. The specific objectives were: $(i)$ to determine if the use of $\theta_{\mathrm{fc}}$-based irrigation scheduling methods could improve seed cotton yield and irrigation water use productivity over the region's traditional irrigation scheduling practices, and (ii) develop a water-saving irrigation management strategy and inform farmers how to implement such a strategy for cotton production in China's extremely arid northwest.

\section{Materials and methods}

\subsection{Study area}

A field experiment was carried out at Cele national station of Observation \& Research for Desert-Grassland Ecosystems, located west of the Qira (also known as Cele) oasis $\left(35^{\circ} 01^{\prime} 20.7^{\prime \prime} \mathrm{N}\right.$ and $80^{\circ} 43^{\prime} 45.9^{\prime \prime} \mathrm{E}$ ). Qira Oasis lies in the middle section of the southern edge of the Taklimakan Desert and at the north foot of Kunlun Mountain, located at $35^{\circ} 17^{\prime} 55^{\prime \prime}-39^{\circ} 30^{\prime} 00^{\prime \prime} \mathrm{N}$ and $80^{\circ} 03^{\prime} 24^{\prime \prime}$ $82^{\circ} 10^{\prime} 34^{\prime \prime} \mathrm{E}$. Elevation at the research site is $1319 \mathrm{~m}$. Located in a continental temperature zone, the region is characterized by a hyper-arid climate with a mean annual precipitation of $35.1 \mathrm{~mm}$, mean annual evaporation from a free water surface of $2596.3 \mathrm{~mm}$, and mean annual temperature of $11.9^{\circ} \mathrm{C}$. The frost-free period is about 196 days. Soil type is mainly aeolian sandy soil, and its $\theta_{\mathrm{fc}}$, total porosity, and bulk density are $19.6 \%, 55.6 \%$ and $1.174 \mathrm{Mg} / \mathrm{m}^{3}$, respectively ${ }^{[4,43,44]}$. Agriculture is the main economic driver in the Qira oasis ecosystem region, with agriculture accounting for $65.63 \%$ of the region's total economic output. Cotton is one of the most important commercial crops in the Qira oasis ${ }^{[29]}$.

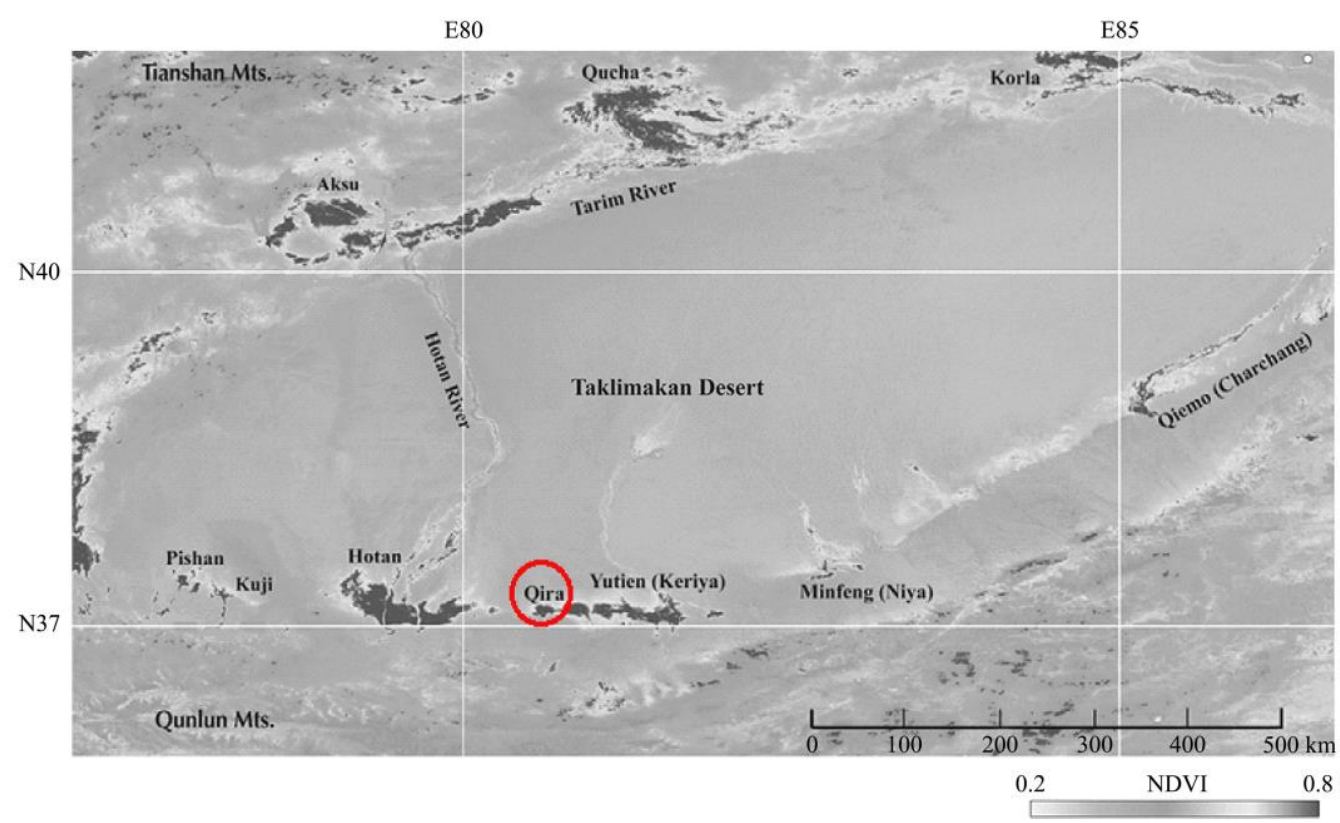

Figure 1 Location of the study area, adapted from Ishiyama et al. ${ }^{[45]}$

\subsection{Experimental design}

Experiment was conducted from May 20, 2011 to October 14, 2011. In this experiment, irrigation water was pumped from a well, surface irrigation was applied using a low-pressure tube water transpiration system with a flow meter to record the water amount that applied to each plot (Figure 2). Four regulated deficit irrigation scheduling treatments based on $\theta_{\mathrm{fc}}$ and an empirical irrigation scheduling (i.e., fixed amount at each growth stage) treatment (CK:Control) were implemented to study the effects of different irrigation regimes on cotton production. The experimental design consisted of thrice-replicated completely randomized blocks. Individual plots were $20 \mathrm{~m} \times 3 \mathrm{~m}$, all plots were separated from each other by a $0.4 \mathrm{~m}$ buffer area. The growing season of the crop was mainly divided into five major growth periods: seedling stage, squaring stage, full-boom stage, boll stage and boll cracking stage. Accordingly, different levels of irrigation replenishment of depleted water from field capacity were performed, and the detailed information on irrigation is provided in Table 1.

Table 1 Treatment setting for field experiment

\begin{tabular}{cccccc}
\hline Treatment & $\begin{array}{c}\text { Seedling } \\
\text { stage }\end{array}$ & $\begin{array}{c}\text { Squaring } \\
\text { stage }\end{array}$ & $\begin{array}{c}\text { Full-boom } \\
\text { stage }\end{array}$ & $\begin{array}{c}\text { Boll } \\
\text { stage }\end{array}$ & $\begin{array}{c}\text { Boll cracking } \\
\text { stage }\end{array}$ \\
\hline T1 & $50 \% \theta_{\mathrm{fc}}$ & $45 \% \theta_{\mathrm{fc}}$ & $40 \% \theta_{\mathrm{fc}}$ & $50 \% \theta_{\mathrm{fc}}$ & $50 \% \theta_{\mathrm{fc}}$ \\
$\mathrm{T} 2$ & $60 \% \theta_{\mathrm{fc}}$ & $50 \% \theta_{\mathrm{fc}}$ & $45 \% \theta_{\mathrm{fc}}$ & $60 \% \theta_{\mathrm{fc}}$ & $60 \% \theta_{\mathrm{fc}}$ \\
$\mathrm{T} 3$ & $70 \% \theta_{\mathrm{fc}}$ & $60 \% \theta_{\mathrm{fc}}$ & $50 \% \theta_{\mathrm{fc}}$ & $70 \% \theta_{\mathrm{fc}}$ & $70 \% \theta_{\mathrm{fc}}$ \\
$\mathrm{T} 4$ & $80 \% \theta_{\mathrm{fc}}$ & $80 \% \theta_{\mathrm{fc}}$ & $70 \% \theta_{\mathrm{fc}}$ & $80 \% \theta_{\mathrm{fc}}$ & $80 \% \theta_{\mathrm{fc}}$ \\
$\mathrm{CK}$ & $120 \mathrm{~mm}$ & $120 \mathrm{~mm}$ & $120 \mathrm{~mm}$ & $120 \mathrm{~mm}$ & $120 \mathrm{~mm}$ \\
\hline
\end{tabular}




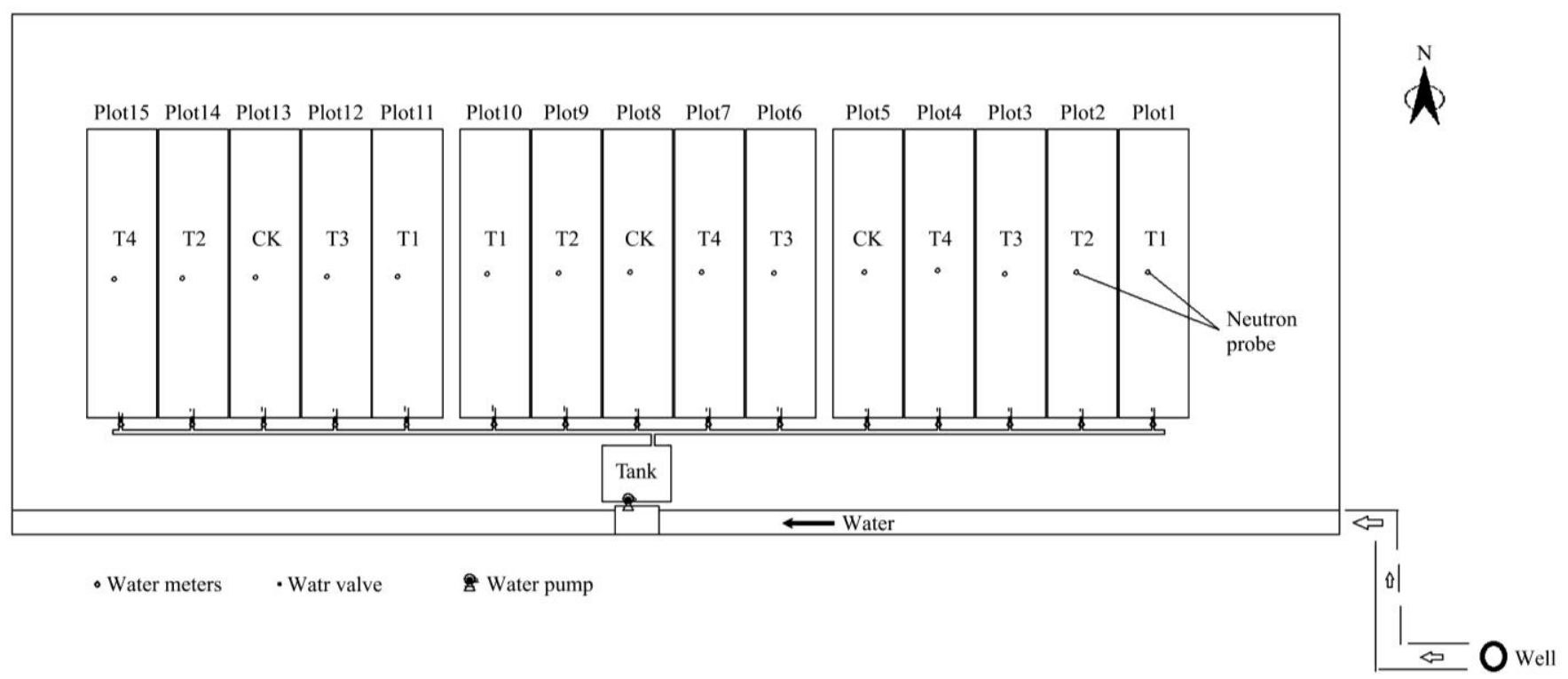

Figure 2 A sketch diagram depiction of the irrigation system used in the study

\subsection{Crop agronomy and management}

On May 20, 2011, cotton (Gossypium hirsutum L., Xinluzhong-21) seeds were planted to the experimental plots at intra- and inter-row spacing of $0.09 \mathrm{~m}$ and $0.25 \mathrm{~m}$, and mulch-covered with $0.08 \mathrm{~mm}$ thickness plastic (polythene) film. This was removed on June 15, 2011 when seedling emergence had reached $100 \%$. Fertilization followed locally recommended rates: farmyard manure applied at $21.500 \mathrm{Mg} / \mathrm{hm}^{2}$ along with inorganic fertilizer totaling at $208 \mathrm{~kg} \mathrm{~N} / \mathrm{hm}^{2}$, along with $57 \mathrm{~kg} \mathrm{P} / \mathrm{hm}^{2}$ in inorganic form. To ensure good germination and initial establishment, $90 \mathrm{~mm}$ of irrigation water was uniformly applied to all treatments on May 19 and thereafter irrigation treatments were regulated. Cultural practices for cotton cultivation were in accordance with the prevalent system of agriculture in the region. Based on on-site observations, crop phenological stages were categorized into five growing stages ${ }^{[46]}$ and recorded.

\subsection{Weather recording and sampling methods}

Rainfall, relative humidity, wind speed, maximum and minimum air temperatures, and solar radiation were measured at a standard meteorological station, locating $10 \mathrm{~m}$ from the experimental site.

Soil samples were collected once a week and further samplings were conducted before and after each irrigation. Volumetric soil water content $(\theta)$ was calculated from difference in weight of fresh soil and oven-dried soil, and each soil layer's bulk density. The $\theta$ was also measured using a neutron probe (CNC100, Probe Science and Technology Ltd., Beijing, China; previously calibrated for the studied soil) in all plots, at 5-day intervals, over twenty $0.005 \mathrm{~m}$ increments, to a depth of $1.000 \mathrm{~m}$. The probes were installed in the middle of rows. Apart from the regular measurements, $\theta$ was also measured $24 \mathrm{~h}$ before and after each irrigation. Data related to crop growth, crop development, and crop yields were collected during the study.

The measurement of soil evaporation $(E)$ began upon removal of the film mulch. Twenty-four micro-lysimeters constructed from PVC tubes (diameter, $0.10 \mathrm{~m}$; height, $0.20 \mathrm{~m}$ ) were installed in the field and weighed daily in the afternoon to a precision of $\pm 0.01 \mathrm{~g}$. The micro-lysimeters were re-installed within one day after each irrigation or heavy rain event (rainfall $>10 \mathrm{~mm}$ ).

To estimate crop water use of cotton, crop evaporation was evaluated by the FAO-56 Penman-Monteith method ${ }^{[46]}$ :

$$
E T_{0}=\frac{0.408 \Delta\left(R_{\mathrm{n}}-G\right)+\gamma \frac{900}{T+273} u_{2}\left(e_{\mathrm{s}}-e_{\mathrm{a}}\right)}{\Delta+\gamma\left(1+0.34 u_{2}\right)}
$$

where, $e_{\mathrm{a}}$ is the actual vapor pressure, $\mathrm{kPa} ; e_{\mathrm{s}}$ is the saturation vapor pressure, $\mathrm{kPa} ; u_{2}$ is the wind speed at $2 \mathrm{~m}$ above the ground surface, $\mathrm{m} / \mathrm{s} ; E T_{0}$ is the reference evapotranspiration, $\mathrm{mm} / \mathrm{d} ; G$ is the soil heat flux, $\mathrm{MJ} / \mathrm{m}^{2} \cdot \mathrm{d} ; R_{\mathrm{n}}$ is the net radiation, $\mathrm{MJ} / \mathrm{m}^{2} \cdot \mathrm{d} ; T$ is the mean daily temperature $2 \mathrm{~m}$ above the ground surface, ${ }^{\circ} \mathrm{C} ; \gamma$ is the psychrometric constant, $\mathrm{kPa} /{ }^{\circ} \mathrm{C}$; and $\Delta$ is the slope of the vapor pressure versus temperature curve, $\mathrm{kPa} /{ }^{\circ} \mathrm{C}$.

Daily $E T_{0}$ and precipitation data for the cotton growing season is shown in Figure 3. Total $E T_{0}$ for the cotton growing season (sum of daily $E T_{0}$ values) was $472.7 \mathrm{~mm}$, while total precipitation for cotton growing season was $3.2 \mathrm{~mm}$.

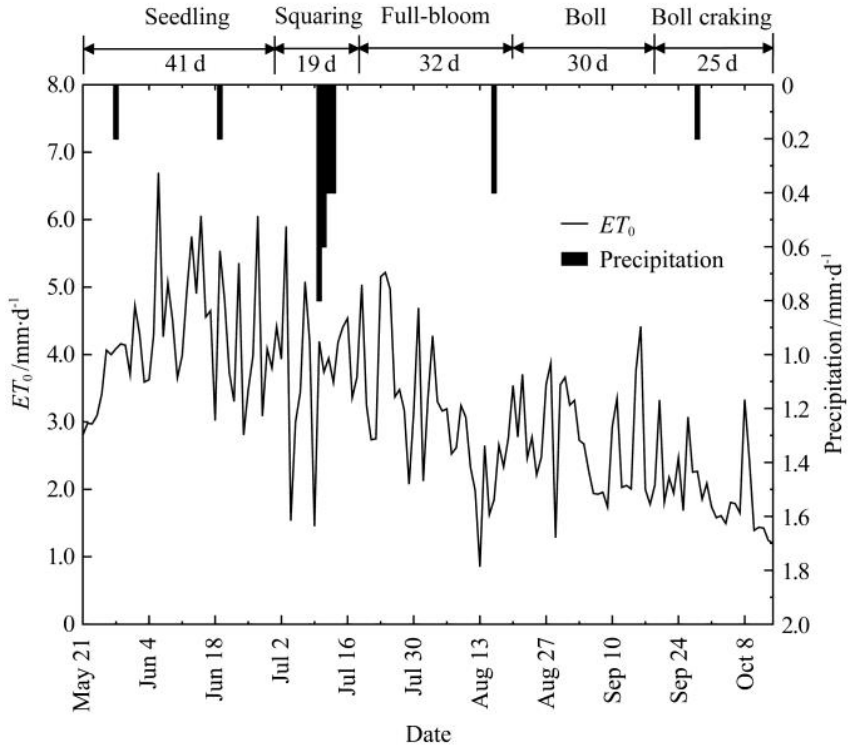

Figure 3 Variation of daily reference evapotranspiration and precipitation during the growth stage of cotton in 2011

Crop consumptive water use can then be estimated by applying single crop coefficient approach to the fields where:

$$
E T_{\mathrm{a}}=K_{\mathrm{c}} \times K_{\mathrm{s}} \times E T_{0}
$$

where, $E T_{\mathrm{a}}$ is actual evapotranspiration $(\mathrm{mm} / \mathrm{d}) ; K_{\mathrm{c}}$ is a crop coefficient; $K_{\mathrm{s}}$ is soil water stress coefficient, and $E T_{0}$ is the reference crop evapotranspiration $(\mathrm{mm} / \mathrm{d})$ estimated from 
meteorological data ${ }^{[47]}$. The value of $K_{\mathrm{c}}$ is derived from experimental data for each crop and relates $E T_{\text {a }}$ to local meteorological conditions through $E T_{0}$. To minimize over and under estimation in irrigation problems, the authors used farmers' experience regarding the numbers of days of each growing stage to estimate reliable $K_{\mathrm{c}}$ values for the respective growing stages.

The recommended values of $K_{\mathrm{c}}$ under sub-humid climate with an average relative humidity $(R H)$ of $45 \%$ and wind speed of $2 \mathrm{~m} / \mathrm{s}$ are well documented in the literature ${ }^{[46]}$. For specific climate conditions where $R H$ differs from $45 \%$ or where wind speed is greater or lesser than $2 \mathrm{~m} / \mathrm{s}$, the $K_{\mathrm{c}}$ value for the mid- or late-season period ( $K_{c, \text { mid }}$ and $K_{c, \text { late }}$, respectively) can be adjusted using the following functions:

$$
\begin{aligned}
& K_{c, \text { mid }}=K_{c, \text { mid }(T a b)}+\left[0.04\left(u_{2}-2\right)-0.004\left(R H_{\text {min, } \text { mid }}-45\right)\right] \cdot\left(\frac{h}{3}\right)^{0.3} \\
& K_{c, \text { late }}=K_{c, \text { late }(T a b)}+\left[0.04\left(u_{2}-2\right)-0.004\left(R H_{\text {min,late }}-45\right)\right] \cdot\left(\frac{h}{3}\right)^{0.3}
\end{aligned}
$$

where, $h$ is the mean plant height during the midseason period, m; $K_{c, \operatorname{mid}(T a b)}$ and $K_{c, \text { late }(T a b)}$ are the values of $K_{c, \text { mid }}$ and $K_{c, \text { late }}$ drawn from Table 12 of the FAO-56 paper ${ }^{[46]}$; and $R H_{\text {min,mid }}$ and $R H_{\text {min,late }}$ are the mean daily minimum relative humidity $(\%)$ during the mid- and late-season periods.

During the crop development and late season stages, $K_{\mathrm{c}}$ varies linearly between the $K_{\mathrm{c}}$ at the end of the previous stage $\left(K_{c, p r e v}\right)$ and the $K_{\mathrm{c}}$ at the beginning of the next stage $\left(K_{c, \text { next }}\right)$, which is $K_{c, \text { end }}$ in the late season stage:

$$
K_{c, i}=K_{c, \text { prev }}+\left[\frac{i-\sum L_{\text {prev }}}{L_{\text {stage }}}\right] \cdot\left(K_{c, \text { next }}-K_{c, \text { prev }}\right)
$$

where, $i$ is the day number within the growing season, $\mathrm{d} ; K_{c, i}$ is the crop coefficient on day $i$; $L_{\text {stage }}$ is the length of the stage under consideration, $\mathrm{d}$; and $\sum L_{\text {prev }}$ is the sum of the lengths of the previous stages, d.

The soil water stress coefficient, $K_{\mathrm{s}}$, was estimated as:

$$
K_{s}=\frac{\ln (A W+1)}{\ln 101} \text {, where } A W=100 \cdot\left(\frac{\theta-\theta_{\text {wp }}}{\theta_{\text {fc }}-\theta_{\text {wp }}}\right)
$$

where, $A W$ is the available water, $\mathrm{mm}$; and $\theta, \theta_{\mathrm{fc}}$, and $\theta_{\mathrm{wp}}$ are the measured, field capacity and permanent wilting point soil moistures expressed in millimeters of water, respectively ${ }^{[48]}$. The $\theta_{\mathrm{fc}}$ and $\theta_{\mathrm{wp}}$ of the $0-1.50 \mathrm{~m}$ soil profile were obtained in lab tests undertaken on undisturbed soils in December 15, 2010, and were $421.8 \mathrm{~mm}$ and $50.3 \mathrm{~mm}$, respectively.

Due to the oasis soil's sandy texture and high saturated hydraulic conductivity $(2.6 \mathrm{~mm} / \mathrm{h})^{[29]}$ surface runoff was excluded. Accordingly, the approximate deep percolation, $D_{s}$ of each plot was determined using the water-balance equation as follows:

$$
\begin{gathered}
D_{s}=P+I-\Delta S-E-T \\
\Delta S=W_{0}-W_{h} \\
T=E T_{a}-E
\end{gathered}
$$

where, $I$ is irrigation, $\mathrm{mm} ; P$ is precipitation, $\mathrm{mm} ; T$ is transpiration of the cotton crop, mm; $W_{0}$ and $W_{h}$ are the initial and final soil water storage in the root zone ( $0-1.50 \mathrm{~m}$ soil profile), $\mathrm{mm}$; while $\Delta S$ is the change in soil water storage from sowing to maturity $(\mathrm{mm})$, which is positive when soil water was consumed and negative when it was recharged.

During the cotton's full-bloom stage, diurnal changes in gas exchange under irrigation treatments were measured every $2 \mathrm{~h}$ from 10:00 to 20:00 on clear days. The net photosynthetic rate $\left(P_{\mathrm{n}}\right)$, transpiration rate $\left(T_{r}\right)$, stomatal conductance $\left(G_{\mathrm{s}}\right)$, and intercellular
$\mathrm{CO}_{2}$ concentration $\left(C_{\mathrm{i}}\right)$ were measured with a portable gas exchange system (Li 6400, LiCOR Inc., Lincoln, NE, USA). Temperature in the leaf chamber was set at $30^{\circ} \mathrm{C}$, carbon dioxide concentration within the leaf chamber was fixed at $400 \mu \mathrm{mol} / \mathrm{mol}$. Meanwhile, photosynthetically active radiation $(P A R)$ was recorded. Fully expanded, healthy and mature broad-ovate leaves in cotton branches, located in the middle part of crown, were placed in the chamber $(20 \mathrm{~mm} \times 90 \mathrm{~mm} \times 30 \mathrm{~mm})$ for measurements. Every measurement was replicated for three times. Data of $P_{\mathrm{n}}, T_{r}$, and $G_{\mathrm{s}}$ were automatically recorded by the machine. The response of cotton leaf photosynthesis to light intensity was measured with a Licor 6400 portable photosynthesis system (Li-Cor, Lincoln, NE, USA). Photosynthetic active radiation (PAR) in a $20 \mathrm{~mm} \times 30 \mathrm{~mm}$ leaf chamber was controlled with an LED light source (red+blue 6400-02B). The PAR gradient was set of 2000, 1800, 1600, 1400, $1200,1000,800,600,400,200,100,50$ and $0 \mu \mathrm{mol} / \mathrm{m}^{2} \cdot \mathrm{s}$, and data were recorded automatically. Temperature and relative humidity in the chamber were controlled at $30^{\circ} \mathrm{C}$ and $20 \%-30 \%$, respectively. Measurements were taken at a local time 10:00-16:00. A light response curve model ${ }^{[49]}$ was used to describe the responses of cotton leaf photosynthesis to light intensity.

Plant roots were carefully excavated, ensuring that the tip of each plant root was obtained, and then weighed. Above ground biomass of cotton were measured on the 49th, 62th, 78th, 101th, 136th day after sowing (DAS), and primary yield components such as number of boll (diameter $>0.02 \mathrm{~m}$ ) per plant, weight of bolls ( $\mathrm{g}$ ), seed cotton weight (g/plant) were also recorded. The seed cotton yield of each plot was monitored by hand harvesting the cotton twice, once before the frost and once after the frost in 2011. All the harvested seed cotton was weighed for each plot to provide a final yield. The WUE in terms of crop evapotranspiration $\left(W U E_{E T}\right)$ was calculated as:

$$
W U E_{\mathrm{ET}}=\frac{Y}{E T_{a}}
$$

where, $Y$ is each plot's total seed cotton yield, and $E T_{a}$ is the total evapotranspiration over the cotton growing season, as calculated in Equation (2).

All the collected data were processed with the SPSS statistical program (version 16.0, SPSS Inc., Chicago, IL, USA). Standard deviations for each treatment were calculated and significance of differences between means was compared by one-way ANOVA with Duncan's multiple range test at significant level of $\mathrm{P}_{0.05}$.

\section{Results and discussion}

\subsection{Crop water requirements of cotton}

The amounts of irrigation water applied at each stage are summarized in Table 2. Compared to CK, the treatments T1, T2, and $\mathrm{T} 3$ saved irrigation water by $37.0 \%, 26.3 \%, 7.3 \%$, respectively, relative to the control. However, under the treatment T4 irrigation water applied increased by $17.7 \%$, relative to the control.

Table 2 Irrigation application rate details of different treatment

\begin{tabular}{clccccc}
\hline \multicolumn{6}{c}{ Amount of irrigation water per treatment/mm } \\
\hline \multirow{6}{*}{$\begin{array}{c}\text { Growth } \\
\text { stages }\end{array}$} & T1 & T2 & T3 & T4 & CK \\
& Pre-sowing & 90 & 90 & 90 & 90 & 90 \\
& Seedling & 72.0 & 86.3 & 115.0 & 148.8 & 120.0 \\
& Squaring stage & 30.9 & 36.7 & 57.0 & 115.1 & 120.0 \\
& Boll-bloom stage & 72.9 & 94.4 & 102.6 & 171.8 & 120.0 \\
& Boll cracking stage & 90.0 & 114.0 & 163.3 & 152.1 & 120.0 \\
\hline & Total & 434.9 & 508.6 & 639.7 & 811.8 & 690.0 \\
\hline
\end{tabular}


Table 3 shows the length of each stage used as to estimate reliable $K_{\mathrm{c}}$ in this study. The value of 0.35 was taken as the initial $K_{\mathrm{c}}$ and the derived values were ranked with mid and late season (Table 3).

Table 3 Crop coefficients during different cotton growth stages

\begin{tabular}{cccccc}
\hline Date & $\begin{array}{c}\text { May 21 to } \\
\text { Jun 12 }\end{array}$ & $\begin{array}{c}\text { June 13 to } \\
\text { July 20 }\end{array}$ & $\begin{array}{c}\text { July 21 to } \\
\text { Sept. 03 }\end{array}$ & $\begin{array}{c}\text { Sept. 03 to } \\
\text { Oct. 14 }\end{array}$ & - \\
\hline Length/d & 23 & 38 & 45 & 41 & - \\
\hline $\begin{array}{c}\text { Crop } \\
\text { coefficients }\end{array}$ & $K_{\mathrm{c}, \text { ini }}$ & $K_{\mathrm{c}, \mathrm{i}}$ & $K_{\mathrm{c}, \text { mid }}$ & $K_{\mathrm{c}, \mathrm{i}}$ & $K_{\mathrm{c}, \text { end }}$ \\
& 0.35 & $0.38-1.46$ & 1.46 & $1.45-0.85$ & 0.85 \\
\hline
\end{tabular}

Soil water stress affects canopy expansion, canopy senescence and $\operatorname{Tr}$ reduction, which are all related to the $K_{\mathrm{s}}^{[50]}$. Daily variation in $K_{\mathrm{s}}$ (Figure $4 \mathrm{a}$ ) shows the effect of water stress on crop transpiration during different cotton growth stages under different irrigation treatments. At the seedling stage, mean daily values of $K_{\mathrm{s}}$ were 0.79 in $\mathrm{T} 1,0.83$ in $\mathrm{T} 2,0.84$ in T3, 0.86 in $\mathrm{T} 4$ and 0.87 in $\mathrm{CK}$, respectively. At the squaring stage, the corresponding value of $K_{\mathrm{s}}$ were 0.76 in T1, 0.80 in T2, 0.83 in T3, 0.88 in T4 and 0.86 in CK, respectively. At the full-bloom stage, mean daily values of $K_{\mathrm{s}}$ were 0.68 in $\mathrm{T} 1,0.71$ in $\mathrm{T} 2,0.74$ in $\mathrm{T} 3,0.82$ in $\mathrm{T} 4$ and 0.80 in $\mathrm{CK}$, respectively. At the boll stage, mean daily values of $K_{\mathrm{s}}$ were 0.72 in T1, 0.79 in T2, 0.79 in T3, 0.86 in T4 and 0.80 in CK, respectively. At the boll cracking stage, mean daily values of $K_{\mathrm{s}}$ were 0.74 in T1, 0.79 in $\mathrm{T} 2,0.83$ in $\mathrm{T} 3,0.84$ in $\mathrm{T} 4$ and 0.80 in CK, respectively.
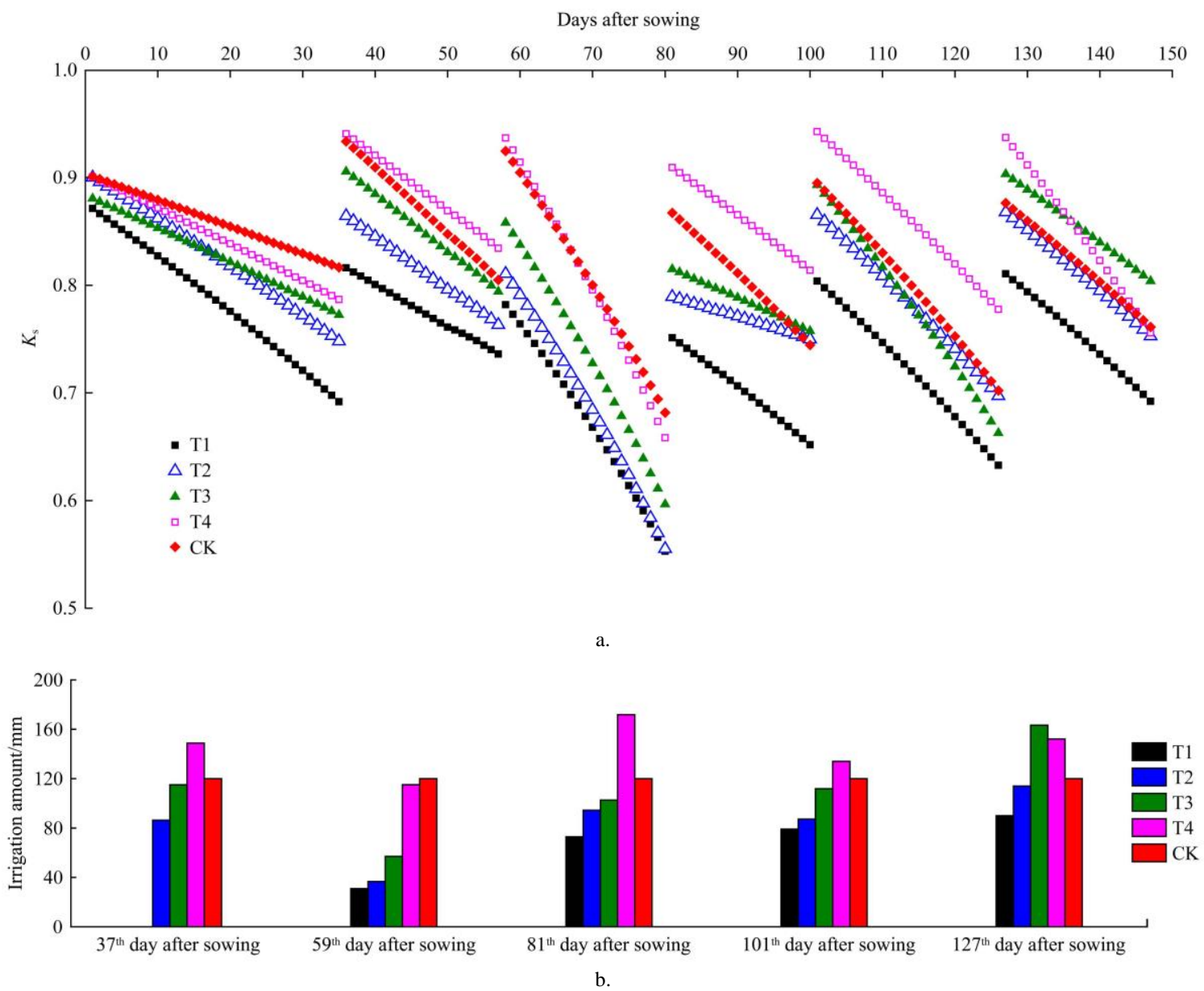

Figure 4 Daily variation of soil water stress coefficient during different cotton growth stages under different irrigation regimes

The measured rate of evaporation from the soil $(E)$ and estimated daily evapotranspiration $\left(E T_{a}\right)$ for cotton were plotted in Figure 5. Regulated deficit irrigation treatments and fixed amount irrigation treatment showed similar trends in $E$ (Figure 5a). The mean value of $E$ in both seedling and squaring stages exceeded $1 \mathrm{~mm} / \mathrm{d}$. The $E$ showed a substantial increase between Day 40 and Day 45 after sowing, which was attributable to the dry winds that cross the Taklamakan desert. During full-boom to boll stage, the mean value of $E$ ranged from 0.7 to $0.9 \mathrm{~mm} / \mathrm{d}$, while at the boll cracking stage it dropped below $0.7 \mathrm{~mm} / \mathrm{d}$. The magnitude of $E$ accounts for a large portion of total loss of irrigation water under field condition, especially in the early crop phenological stages when the canopy is small.

Trends in $E T_{a}$ under regulated deficit irrigation were almost the same as those under the control treatment (Figure 5b). The low cotton crop evapotranspiration rates (mean between 2.0 to $2.2 \mathrm{~mm} / \mathrm{d}$ ) which occurred from the sowing to the seedling stage were attributable to soil evaporation being inhibited and $E T_{a}$ being dominated by transpiration under film mulching. Nevertheless, the daily $E T_{a}$ of cotton gradually increased from the squaring stage onward, and even exceeded $10 \mathrm{~mm} / \mathrm{d}$ at the full-boom stage. Furthermore, in most growing periods, $E / E T_{a}$ was significantly affected by irrigation depth. With $E$ accounting for more than $20 \%$ of $E T_{a}$, a significant level of ineffective water dissipation occurred in the cotton field, indicating that the proper crop management's water saving potential must be considered when irrigating cotton in a hyper-arid area.

The water-balance components of cotton transpiration and deep percolation increased with an increase in the depth of irrigation (Table 4). It should be noted that consumption of stored soil water for plant growth led to soil water depletion in the $0-1.50 \mathrm{~m}$ soil profile. The high water depletion in $\mathrm{T} 1$ and $\mathrm{T} 2$ could be the result of evapotranspiration of cotton that mainly supplemented by increasing stored soil water use due to insufficient 
irrigation and rainfall. However, the least soil water depletion occurred under T3, demonstrating that a suitable water supply may result in a considerable greater $W U E$ while maintaining a dynamic soil water balance within the root zone. Irrigation also significantly affected water requirement of cotton. Along with the increase in the quantity of irrigation came the increase in ET over the full cotton growing season (Table 5). Moreover, the cotton crop's water requirements showed significant differences at

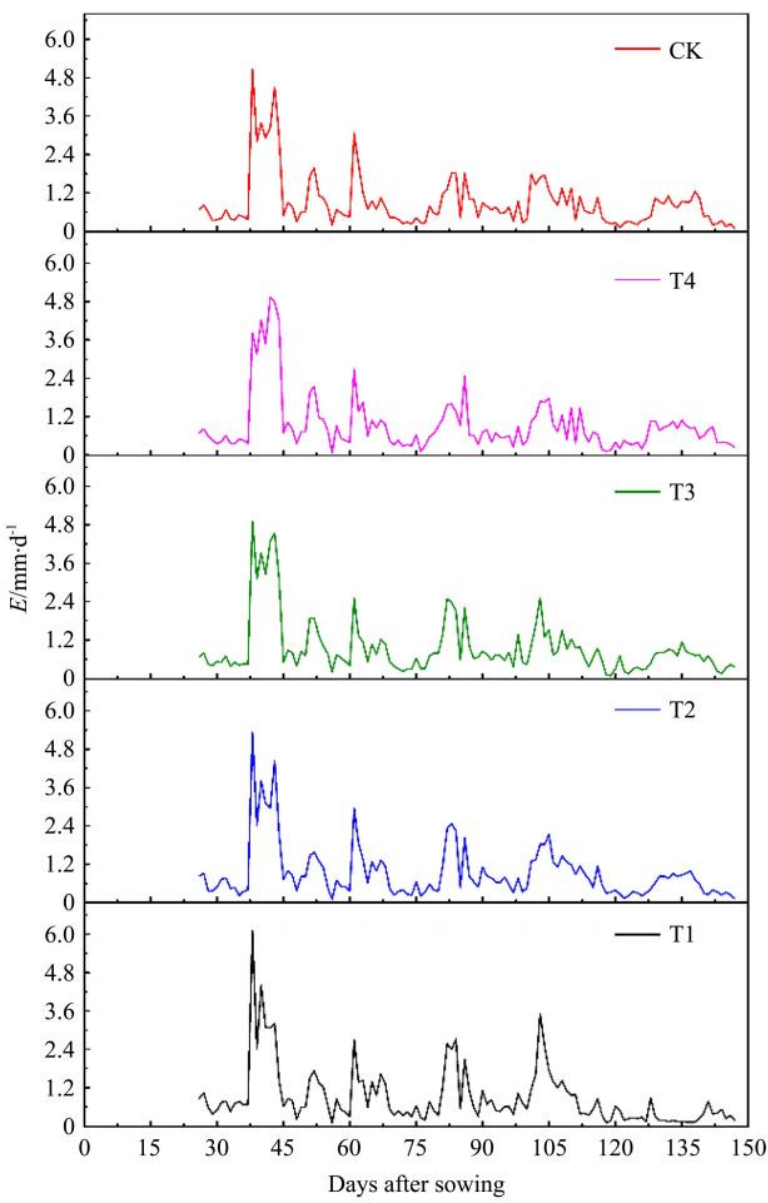

a. different growing stages. In both the seedling and squaring stages, cotton growth accounted for a relatively small share of water use. In contrast, over half the water was consumed during the flowering and boll-forming stage. The lowest water consumption occurred during the boll cracking stage. This clearly indicates that any irrigation regime for cotton should be made according to crop water requirement, rather than a fixed schedule with same amount in different growth stages.

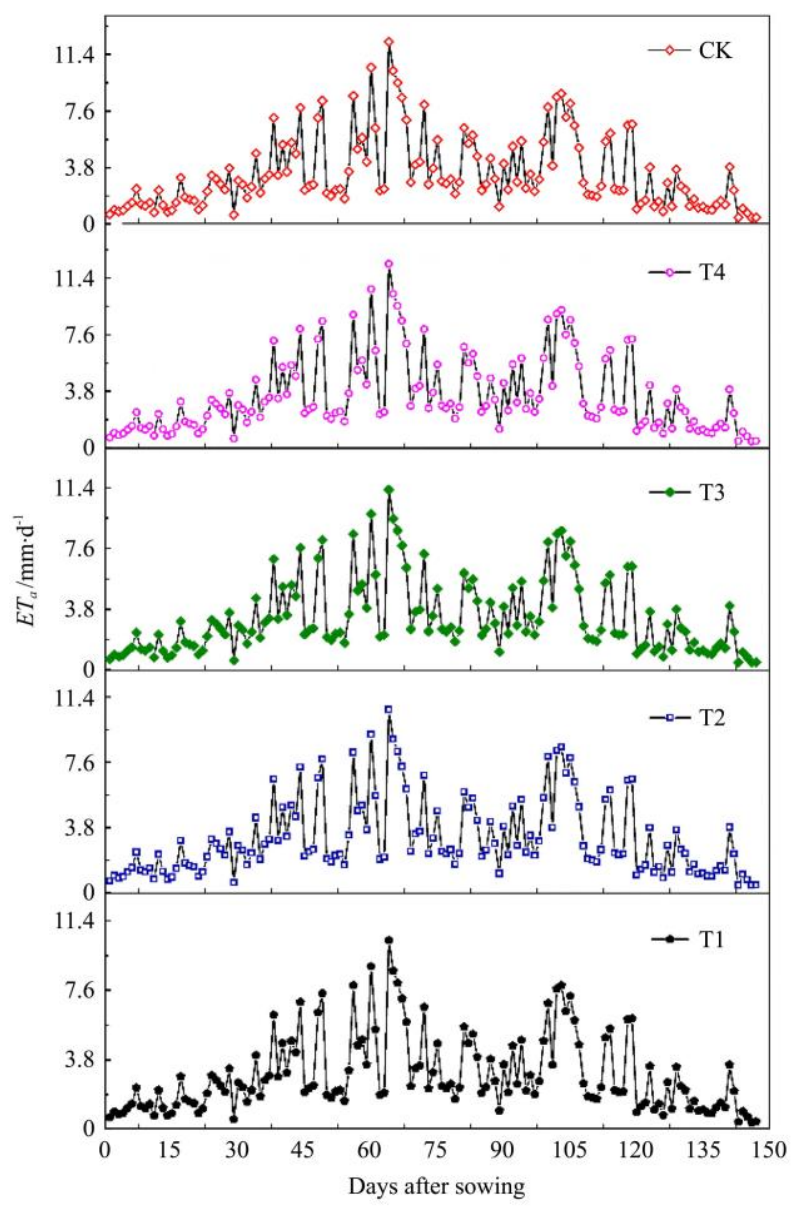

$\mathrm{b}$

Figure 5 Daily variation in soil evaporation (a) and evapotranspiration (b) during various cotton growth stages under different irrigation treatments

Table 4 Water balance analysis results during the growing period of cotton

\begin{tabular}{ccccccc}
\hline \multirow{2}{*}{ Treatment } & \multicolumn{6}{c}{ Water balance parameter/mm } \\
\cline { 2 - 7 } & $I$ & $P$ & $E$ & $T$ & $D_{S}$ & $\Delta S$ \\
\hline T1 & 345.0 & 3.2 & 110.5 & 330.0 & 26.1 & -118.4 \\
T2 & 418.6 & 3.2 & 114.1 & 353.5 & 77.1 & -122.9 \\
T3 & 549.7 & 3.2 & 117.1 & 365.6 & 135.9 & -65.7 \\
T4 & 721.8 & 3.2 & 115.2 & 400.2 & 328.5 & -118.9 \\
CK & 600.0 & 3.2 & 110.0 & 390.8 & 220.3 & -117.9 \\
\hline
\end{tabular}

Table 5 Water use of cotton over the full growing period $(\mathrm{mm})$

\begin{tabular}{ccccccc}
\hline Treatment & $\begin{array}{c}\text { Seedling } \\
\text { stage }\end{array}$ & $\begin{array}{c}\text { Squaring } \\
\text { stage }\end{array}$ & $\begin{array}{c}\text { Full-boom } \\
\text { stage }\end{array}$ & $\begin{array}{c}\text { Boll } \\
\text { stage }\end{array}$ & $\begin{array}{c}\text { Boll cracking } \\
\text { stage }\end{array}$ & Total \\
\hline T1 & 81.6 & 86.3 & 120.4 & 114.7 & 37.4 & 440.5 \\
T2 & 86.3 & 90.1 & 125.3 & 125.6 & 40.4 & 467.7 \\
T3 & 87.9 & 94.4 & 131.6 & 127.0 & 41.8 & 482.7 \\
T4 & 90.2 & 99.9 & 144.6 & 137.7 & 42.9 & 515.4 \\
CK & 91.3 & 97.9 & 142.4 & 128.5 & 40.8 & 500.9 \\
\hline
\end{tabular}

3.2 Water use efficiency of cotton from a photosynthetic perspective

It can be seen from Figure $6 \mathrm{a}$ that daily changes of photosynthetically active radiation (PAR) presented a unimodal curve, with $P A R$ increasing antemeridian, and reaching a maximum at 14:00, thereafter declining until sundown. The transpiration rate of cotton leaves $\left(T_{r}\right)$ showed significant differences among irrigation treatments $(p \leq 0.05)$ (Figure $6 \mathrm{~b})$. Presenting a unimodal curve under T1, T2, T4 and CK, $T_{r}$ showed its peak value at 14:00. In contrast, diurnal variation in transpiration rate showed a bimodal curve under $\mathrm{T} 3$, demonstrating that $T_{r}$ was strongly affected by water conditions.

Similarly, diurnal characteristics of stomatal conductance $\left(G_{s}\right)$ differed among irrigation treatments. The peak value under regulated deficit irrigation treatments occurred at 14:00, whereas the peak value occurred at 12:00 in control. The $G_{s}$ of cotton leaves was positively correlated with the amount of irrigation water, since water deficits induced closure stomata (Figure 6c). Variation in intercellular $\mathrm{CO}_{2}$ concentration $\left(C_{i}\right)$ under different irrigation treatments followed similar patterns. Diurnal variations 
of $C_{i}$ declined from 10:00 to mid-day and then increased, the lowest value occurring at 12:00 under the $\mathrm{T} 3$ treatment, whereas it occurred at 14:00 for other treatments (Figure 6d). These variations were mainly attributable to diurnal changes in cotton plants' photosynthetic abilities ${ }^{[51]}$.

Figure 7a present the diurnal course of the net photosynthetic rate $\left(P_{n}\right)$ of cotton leaves under different irrigation treatments. The $P_{n}$ showed a single-peaked curve with the highest value occurring at 14:00, which concurred with a time of strong transpiration, and with a subsequent late afternoon drop in photosynthesis. Such phenomenon might be explained by lower stomatal conductance under water stress, which led to a lower net

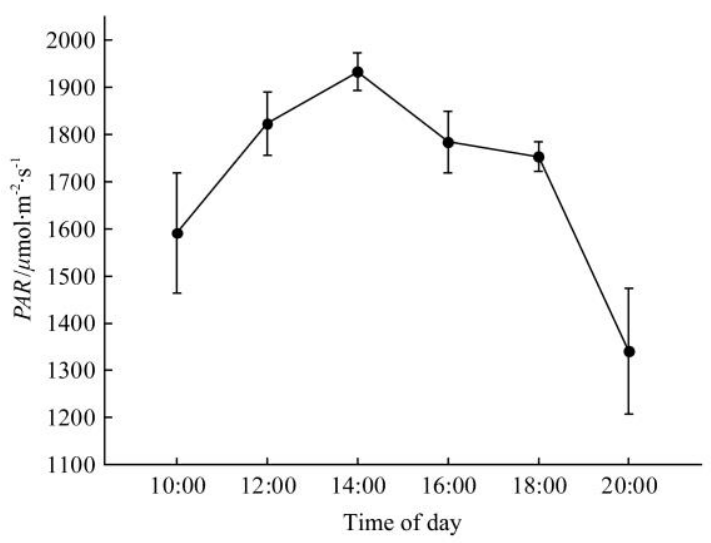

a.

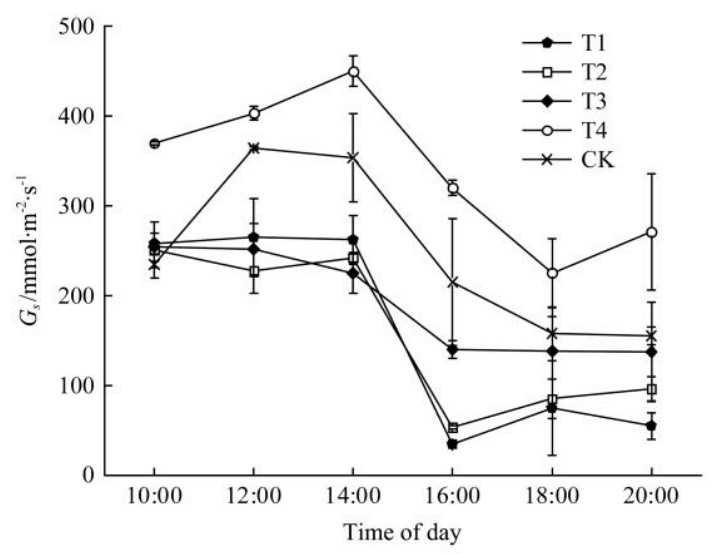

c. photosynthetic rate. Figure 7a also showed that $P_{n}$ under T4 was significantly higher than that under other treatments; however, there was no significant difference in $P_{n}$ between T3 and CK $(p>0.05)$, indicating that moderate water stress does not significantly reduce the net photosynthetic rate of cotton. A descending trend of cotton leaves' WUE was generally found over the course of the day (Figure 7b), and marked differences in $W U E$ existed among the different irrigation treatments $(p \leq 0.05)$. Compared with the fixed amount irrigation treatment, deficit irrigation resulted in $16.8 \%, 10.3 \%$ and $2.2 \%$ increase of leaf $W U E$ (mean value from 10:00 am to 20:00 pm) under T1, T3 and T4, respectively.

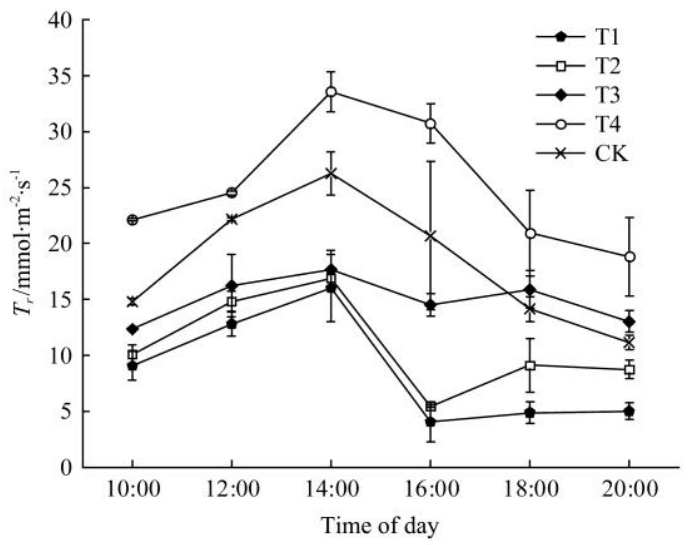

b.

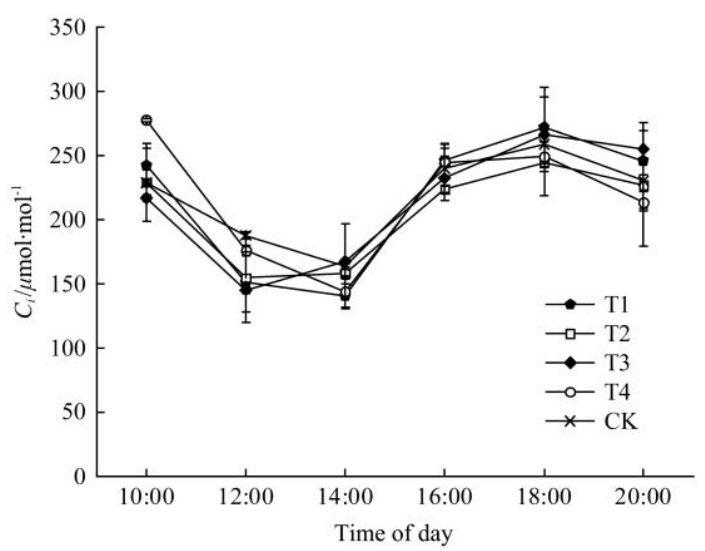

d.

Figure 6 Diurnal pattern of photosynthetically active radiation $(P A R)(\mathrm{a})$, transpiration rate $\left(T_{r}\right)(\mathrm{b})$, stomatal conductance $\left(G_{s}\right)(\mathrm{c})$, and intercellular $\mathrm{CO}_{2}$ concentration $\left(C_{i}\right)(\mathrm{d})$ under different irrigation treatment, measured on August 4, 2011

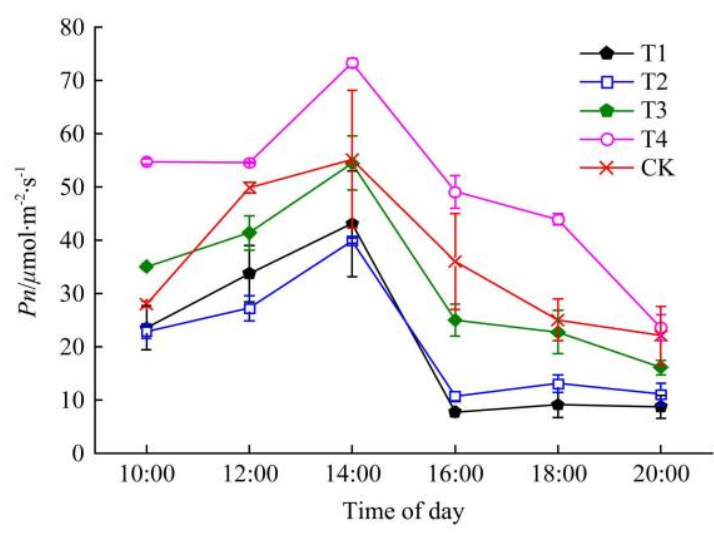

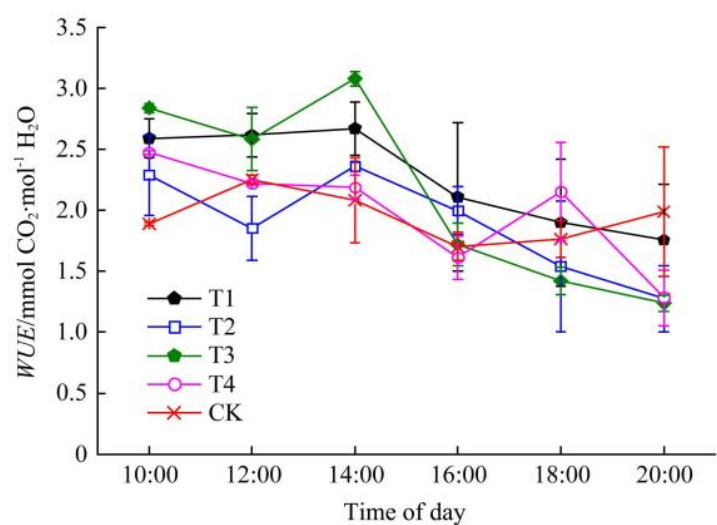

b.

Figure 7 Diurnal course of the net photosynthetic rate (a) and the water use efficiency (b) of cotton leaves under different irrigation treatment

For all treatments, response curves of $P_{n}$ and leaf $W U E$ to light intensity (Figure 8), show $P_{n}$ to increase with an increase in $P A R$ over the range of $0-800 \mu \mathrm{mol} / \mathrm{m}^{2} \cdot \mathrm{s}$, and remain steady in the range of $800-2000 \mu \mathrm{mol} / \mathrm{m}^{2} \cdot \mathrm{s}$ (Figure $8 \mathrm{a}$ ). The response curves of $W U E$ to 
light intensity showed similar trend under variant irrigation treatments. The WUE significantly increased with an increase of $P A R$ in a range of $0-600 \mu \mathrm{mol} / \mathrm{m}^{2} \cdot \mathrm{s}$, whereas the change of WUE slowed when $P A R$ exceeded $600 \mu \mathrm{mol} / \mathrm{m}^{2} \cdot \mathrm{s}$ (Figure $8 \mathrm{~b}$ ). These results indicated that cotton could show a potential ability for photosynthesis under stronger light intensity, without water loss as a price. Figure 8 also showed that both $P_{\mathrm{n}}$ and $W U E$ in control plot were the lowest among all treatments. These two parameters reached their highest value under $\mathrm{T} 4$ when $P A R$ exceeded $100 \mu \mathrm{mol} / \mathrm{m}^{2} \cdot \mathrm{s}$. It is accordingly demonstrated that water stress can improve leaf $W U E$ within a certain range of light intensities. Nonetheless, the improvement of WUE requires better water conditions with strong light intensities.
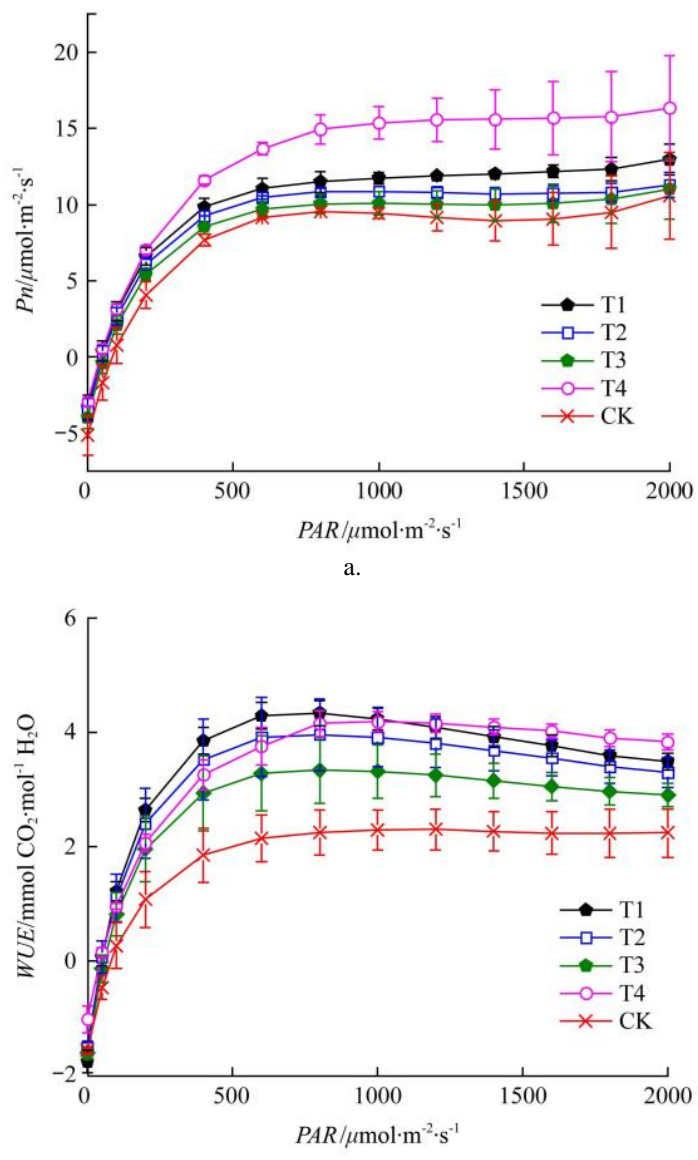

b.

Figure 8 Response curves of the net photosynthetic rate (a) and leaf water use efficiency (b) to light intensity under different irrigation treatment

\subsection{Water use efficiency of cotton from a yield perspective}

Above-ground biomass differed significantly among different irrigation treatments (Figure 9a), indicating that the quantity of irrigation amount had a significant effect on dry matter accumulation in cotton. On the $49^{\text {th }}$ day after sowing, above-ground biomass of cotton and its rate of accumulation under $\mathrm{T} 3$ was significantly greater than that under $\mathrm{T} 1$ or $\mathrm{T} 4$ irrigation regimes $(p \leq 0.05)$, whereas there were no significant differences $(p>0.05)$ between T2, T3 and CK (Figure 9b). Furthermore, above-ground biomass under $\mathrm{T} 3$ showed no noticeable reduction compared with CK, even at the boll cracking stage (i.e. 136 DAS). The quantity of irrigation applied not only affected the biomass accumulation of cotton, but also impacted the distribution of biomass in different organs. As a result, significant differences were observed in the partitioning of plant organs (stems, leaves, reproductive organs) at specific growth stages (Figures 9c-9e).

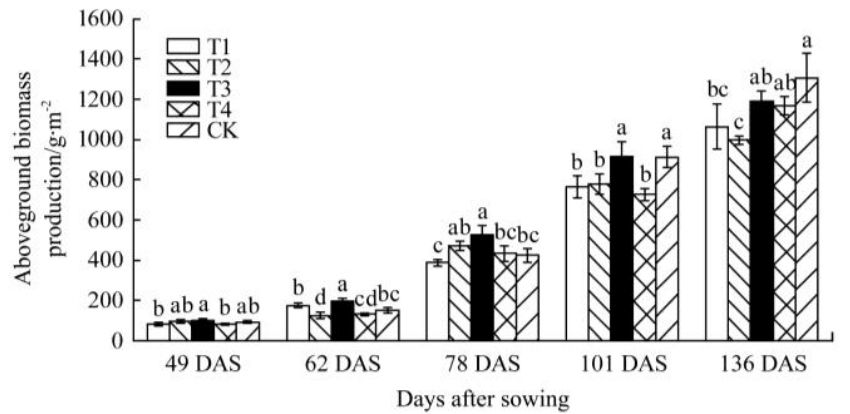

a.

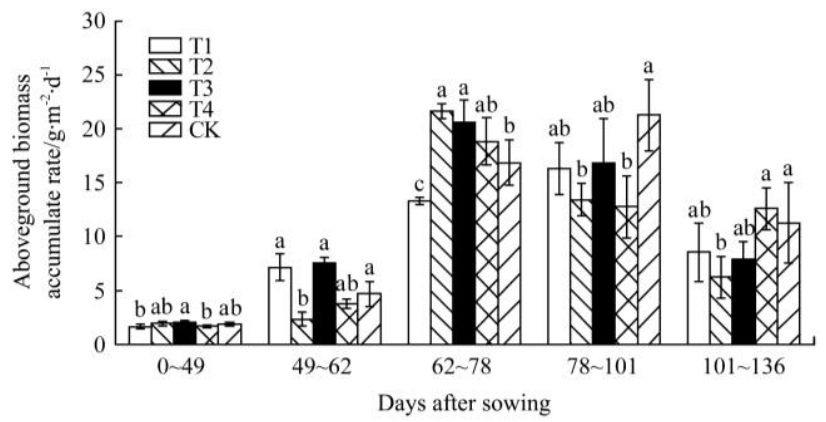

b.

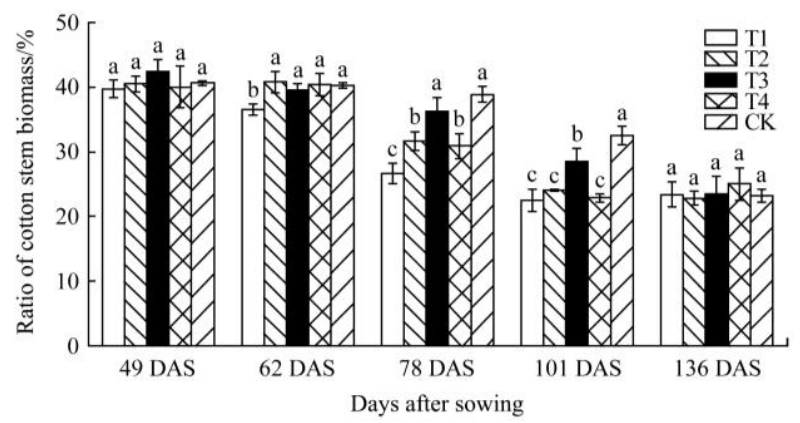

c.

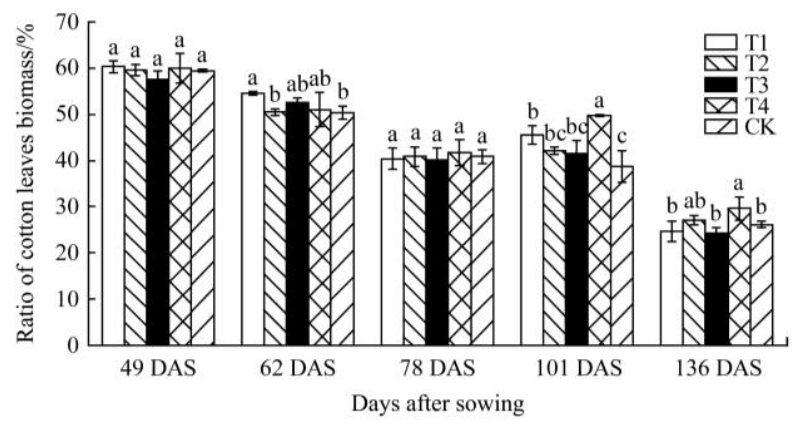

d.

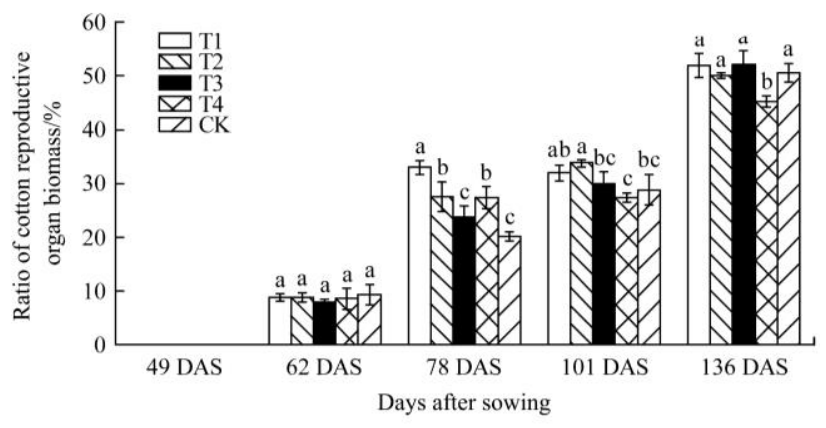

e.

Note: Different letters within a sampling date grouping represent a significant difference among irrigation regimes $(p \leq 0.05)$.

Figure 9 Above-ground biomass production of cotton (a) and the above-ground biomass accumulation rate (b), ratio of cotton stem

biomass(c), ratio of cotton stem biomass (d), ratio of cotton reproduction organ biomass (e) under different irrigation treatments 
For example, the ratio of cotton stem biomass under T2 was obviously lower than that of other treatments on DAS 62, while the ratio of cotton leaves under $\mathrm{T} 1$ was distinctly higher than that under $\mathrm{T} 2$ and $\mathrm{CK}$ at the same time, but there were no distinguishing differences in the relative biomass reproductive organs across different treatments $(p>0.05)$. On DAS 101, the proportion of leaf biomass under T4 was significantly greater than that under other treatments $(p \leq 0.05)$. In other words, compared with $\mathrm{CK}$, a greater water supply promoted the distribution of dry matter towards the leaves, whereas it inhibited the distribution of biomass into reproductive organs. Above-ground biomass distributed in vegetative organs under $\mathrm{T} 3$ showed the smallest proportion at 136 DAS. In contrast, a greater proportion of total biomass was apportioned to reproductive structures under $\mathrm{T} 3$, which benefited the formation of economic yield. This clearly illustrates the importance of adequately regulated irrigation scheduling for cotton growth.

Cotton rooting depth decreased with an increase in the quantity of irrigation applied at most growth stages, except DAS 62 to DAS 78 , when root depth under T3 was significantly greater than under other irrigation regimes (Table 6). As crop root zone $A W$ decreased, cotton plants extracted more water from greater depths by reaching deeper into the soil profile. Regulated irrigation may help improve crop root systems, particularly when a moderate water stress was imposed at the full-bloom stage. This might be an agronomic adaptation of cotton to water stress in water-scarce or arid regions ${ }^{[52,53]}$. With respect to root dry mass, results differed from those of root depth. At DAS 49 and DAS 78 root dry matter under T3 was obviously greater than under other irrigation regimes, whereas T1 showed the greatest root dry mass at DAS 62, DAS 101 and DAS 136. This demonstrated an increasing trend in root biomass with decrease of irrigation volume.

Table 6 Root depth and dry matter under different irrigation treatments at different sampling dates after sowing

\begin{tabular}{ccccccc}
\hline & & \multicolumn{5}{c}{ Day after sowing } \\
\cline { 3 - 7 } & & 49 & 62 & 78 & 101 & 136 \\
\hline \multirow{2}{*}{$\begin{array}{c}\text { Root depth } \\
\text { /m }\end{array}$} & $\mathrm{T} 1$ & $0.380 \mathrm{a}$ & $0.682 \mathrm{a}$ & $0.916 \mathrm{~b}$ & $1.358 \mathrm{a}$ & $1.413 \mathrm{a}$ \\
& $\mathrm{T} 2$ & $0.377 \mathrm{a}$ & $0.668 \mathrm{a}$ & $0.882 \mathrm{~b}$ & $1.307 \mathrm{~b}$ & $1.314 \mathrm{~b}$ \\
& $\mathrm{~T} 3$ & $0.368 \mathrm{~b}$ & $0.683 \mathrm{a}$ & $0.974 \mathrm{a}$ & $1.297 \mathrm{~b}$ & $1.340 \mathrm{~b}$ \\
& $\mathrm{~T} 4$ & $0.336 \mathrm{~b}$ & $0.586 \mathrm{~b}$ & $0.775 \mathrm{~d}$ & $0.986 \mathrm{c}$ & $1.028 \mathrm{c}$ \\
& $\mathrm{CK}$ & $0.343 \mathrm{~b}$ & $0.595 \mathrm{~b}$ & $0.804 \mathrm{c}$ & $1.017 \mathrm{c}$ & $1.156 \mathrm{c}$ \\
\hline \multirow{3}{*}{$\begin{array}{c}\text { Root dry matter } \\
\text { per plant/kg }\end{array}$} & $\mathrm{T} 1$ & $0.59 \mathrm{~b}$ & $2.2 \mathrm{a}$ & $3.5 \mathrm{~b}$ & $5.7 \mathrm{a}$ & $5.4 \mathrm{a}$ \\
& $\mathrm{T} 2$ & $0.56 \mathrm{~b}$ & $1.6 \mathrm{~b}$ & $3.8 \mathrm{~b}$ & $5.6 \mathrm{a}$ & $5.3 \mathrm{a}$ \\
& $\mathrm{T} 3$ & $0.66 \mathrm{a}$ & $1.8 \mathrm{~b}$ & $4.4 \mathrm{a}$ & $5.3 \mathrm{a}$ & $5.3 \mathrm{a}$ \\
& $\mathrm{CK}$ & $0.50 \mathrm{c}$ & $1.5 \mathrm{~b}$ & $3.6 \mathrm{~b}$ & $5.3 \mathrm{~b}$ & $5.1 \mathrm{~b}$ \\
\hline
\end{tabular}

Note: Different letters column-wise for each root parameter and sampling time represent a significant difference among irrigation regimes $(p \leq 0.05)$.

Cotton yield is dependent on the production and retention of bolls, which both can be decreased by water stress ${ }^{[54]}$. The number of cotton bolls and the weight per boll under different irrigation regimes were measured (Table 7). Though there were numerically fewer bolls per plant under T1, T2, and T4 (vs. T3 and CK), these differences were not statistically significant $(P>0.05)$. However, individual boll weight under T1 was significantly lower than under other treatments $(p<0.05)$. Remarkably, there was no significant difference in the boll weight between T3 and CK. The results showed that an insufficient or excess irrigation water supply could be inhibitive to the formation of seed yield, but that moderate water deficits increased both the number of bolls per plant and boll weight, thereby contributing to the improvement of seed yield. These results may be attributed to the different ratios of reproductive organ biomass to total biomass mentioned above.

Table 7 Cotton boll number per plant and single boll weight under different irrigation regimes

\begin{tabular}{ccc}
\hline Treatments & Bolls per plant & Boll weight $/ \mathrm{g} \cdot \mathrm{boll}^{-1}$ \\
\hline T1 & $3.7 \pm 0.4 \mathrm{a}$ & $4.4 \pm 0.1 \mathrm{~b}$ \\
T2 & $3.8 \pm 0.6 \mathrm{a}$ & $4.4 \pm 0.2 \mathrm{ab}$ \\
T3 & $4.1 \pm 0.6 \mathrm{a}$ & $4.7 \pm 0.3 \mathrm{a}$ \\
T4 & $3.2 \pm 0.5 \mathrm{a}$ & $4.5 \pm 0.3 \mathrm{ab}$ \\
CK & $4.1 \pm 0.5 \mathrm{a}$ & $4.7 \pm 0.2 \mathrm{a}$ \\
\hline
\end{tabular}

Note: Different letters column-wise for each boll parameter represent a significant difference among irrigation regimes $(p \leq 0.05)$.

It is noteworthy that cotton yields under T1, T2 and T4 were lower than those under the control, whereas under $\mathrm{T} 3$ a relatively high seed yield was achieved (Table 8). Thus, it was clear that a specific regime of regulated deficit irrigation could contribute to an increase in seed cotton yield in an extremely arid area. The high yield under the $\mathrm{T} 3$ treatment was attributable to the maintenance of a favorable moisture regime for the cotton plant over a longer period of time, resulting in better root growth and leading to greater yield attribute values ${ }^{[37]}$.

Table 8 Cotton yield under different $\theta_{\mathrm{fc}}$-based irrigation regimes relative to the yield under the set quantity control irrigation regimes (control yield $3.097 \mathbf{M g} \cdot \mathbf{h m}^{-2}$ )

\begin{tabular}{|c|c|c|c|c|c|}
\hline \multirow{3}{*}{$\begin{array}{c}\text { Treatm } \\
\text { ents }\end{array}$} & \multirow{3}{*}{$\begin{array}{l}\text { Cotton yield } \\
/ \mathrm{Mg} \cdot \mathrm{hm}^{-2}\end{array}$} & \multicolumn{4}{|c|}{$\begin{array}{l}\text { Comparison between regulated-irrigation treatments } \\
\text { and control }\end{array}$} \\
\hline & & \multicolumn{2}{|c|}{ Reduction } & \multicolumn{2}{|c|}{ Increase } \\
\hline & & $\begin{array}{l}\text { Absolute } \\
/ \mathrm{kg}^{-\mathrm{hm}^{-2}}\end{array}$ & $\begin{array}{l}\text { Relative } \\
1 \%\end{array}$ & $\begin{array}{l}\text { Absolute } \\
/ \mathrm{kg} \cdot \mathrm{hm}^{-2}\end{array}$ & $\begin{array}{l}\text { Relative } \\
1 \%\end{array}$ \\
\hline $\mathrm{T} 1$ & 2.555 & 541.7 & $17.5 \%$ & - & - \\
\hline $\mathrm{T} 2$ & 2.791 & 305.6 & $9.9 \%$ & - & - \\
\hline $\mathrm{T} 3$ & 3.122 & - & - & 25.0 & $0.8 \%$ \\
\hline $\mathrm{T} 4$ & 3.016 & 80.6 & $2.6 \%$ & - & - \\
\hline
\end{tabular}

A significant $(p \leq 0.01)$ second degree polynomial relationship best approximated the relationship between water use and seed cotton yield (Figure 10a). Cotton yield increased as water use $\left(E T_{a}\right)$ increased, but reached the maximum value when $E T_{a}$ was $482.7 \mathrm{~mm}$. The highest $W U E$ was achieved under T3: $W U E_{\mathrm{ET}}=$ $0.65 \mathrm{~kg} / \mathrm{m}^{3}$ (Figure 10b). With a decrease in irrigation volume, WUE of cotton under $\mathrm{T} 1$ and $\mathrm{T} 2$ showed a decreasing trend compared with that under the control irrigation regime. This shows that under deficit irrigation management, T1 and T2 are not conducive to the improvement of $W U E$ of cotton. These findings indicated that only within an appropriate range of water deficit, yield and WUE of cotton can be obtained. These results concur with those of Yang et al. ${ }^{[21]}$, who reported a positive effect of moderate water deficit on water productivity in cotton. The increase in $W U E_{\mathrm{ET}}$ under deficit irrigation can be attributed to several factors: the reduction of losses due to evaporation and the increase in yield parameters ${ }^{[33]}$. Given that in hyper-arid areas agricultural production relies heavily on irrigation ${ }^{[55]}$, farmers hypothesized that, compared to the conventional irrigation regime, supplying the cotton crop with a greater water supply during the growing season could significantly increase $W U E$ and yield ${ }^{[56]}$. However, this hypothesis was not compatible with results of this study. In this study, irrigation volume was increased to a level 
that exceeding the conventional irrigation regime, and the increase of irrigation amount under T4 did not enhance the seed cotton yield but reduced the WUE, which indicated that increase in $A W$ was not efficiently utilized.

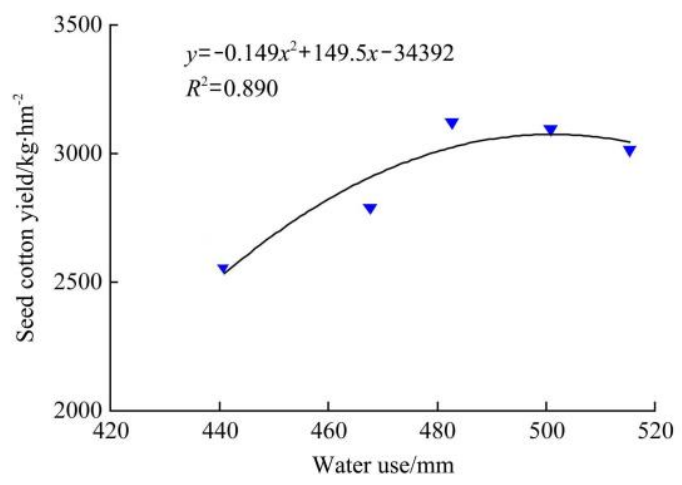

a.

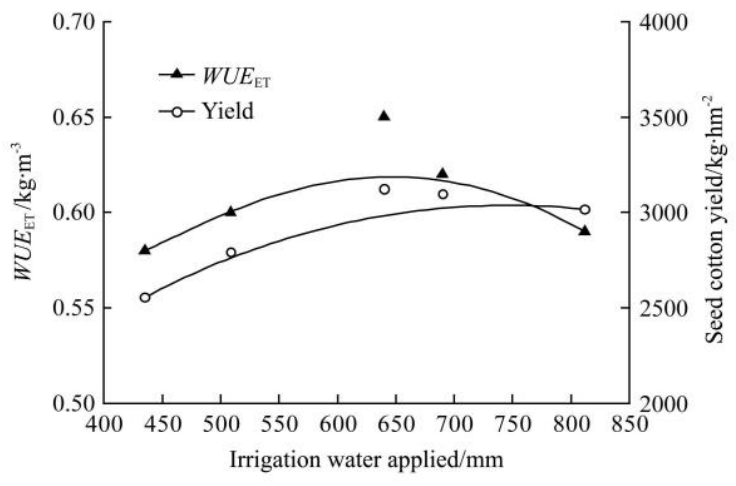

b.

Figure 10 Relationship of between seed cotton yield and water use (evapotranspiration) (a) and interaction between seed cotton yield and water use efficiency (b)

\section{Conclusions}

In summary, the present study tested the hypothesis that field $\theta_{\mathrm{fc}}$-based regulated deficit irrigation could improve the WUE and seed yield of cotton. Compared to traditional flood irrigation, the treatments T1, T2, and T3 saved irrigation water by $37.0 \%, 26.3 \%$, $7.3 \%$, respectively. However, the lowest value of soil water depletion was found in T3, demonstrated that a suitable water supply can sustain a dynamic soil water balance of the root zone. Moreover, more than $50 \%$ of the water was consumed during the flowering and boll-forming stage, while the lowest water consumption occurred at the boll cracking stage. The irrigation plan for cotton should be developed according to crop water requirements rather than a fixed schedule with fixed amounts at different crop growth stages. From a photosynthetic perspective, compared with CK, deficit irrigation resulted in $16.8 \%, 10.3 \%$ and $2.2 \%$ increase of leaf $W U E$ under T1, T3 and T4, respectively. On the other hand, cotton yield and its components were significantly affected by irrigation amounts. A relatively high seed yield (increased by $7 \%$ compared to $\mathrm{CK}$ ) and the highest $W U E_{\mathrm{ET}}$ were achieved under $\mathrm{T} 3$, with the value of $0.65 \mathrm{~kg} / \mathrm{m}^{3}$. Consistent with these results, Shareef et al. also reported that drought induced interactive changes in physiological and biochemical attributes of cotton according to the field capacity based deficit irrigation experiment in the same area in 2015 and 2016. Thus, deficit irrigation could necessarily be an appropriate yield optimization and water saving technique for cotton in desert environment ${ }^{[22]}$. Application of $\theta_{\mathrm{fc}}$-based regulated deficit irrigation in surface-irrigated cotton fields showed great potential towards saving water, improving seed cotton yield and maintaining high $W U E$ in an extremely arid region in northwest China. In the present study, the T3 irrigation regime offered the maximal effectiveness and productivity. Accordingly, the irrigation management strategy that should be implemented in that regions would be one where root-zone soil moisture at the seedling stage would trigger irrigation when $\theta<0.7 \theta_{\mathrm{fc}}$, while at the squaring, full-bloom, boll and boll cracking stages, the threshold root zone soil moistures would be $0.6 \theta_{\mathrm{fc}}, \quad 0.5 \theta_{\mathrm{fc}}, \quad 0.7 \theta_{\mathrm{fc}}$, and $0.7 \theta_{\mathrm{fc}}$, respectively. The farmers in this extremely arid region should be encouraged to irrigate based on $\theta_{\mathrm{fc}}$, and regulate deficit irrigation to increase the efficient use of stored soil water in the root zone and, thus promote agricultural sustainability.

\section{Acknowledgements}

The authors wish to acknowledge the funding from Xinjiang Thousand Youth Talents Plan Project (Y672071001), the Doctoral Foundation of Jiangxi Agricultural University (9232304717), the China Scholarship Council program (CSC, 201608360137) and the National Natural Science Foundation of China (NSFC, U1603343). The authors also thank the anonymous reviewers for their critical comments and suggestions for improving the manuscript.

\section{[References]}

[1] Yang H, Du T S, Qiu R J, Chen J L, Wang F, Li Y, et al. Improved water use efficiency and fruit quality of greenhouse crops under regulated deficit irrigation in northwest China. Agricultural Water Management, 2017; 179(Supplement C): 193-204.

[2] Xue J Y, Huo Z L, Wang F X, Kang S Z, Huang G H. Untangling the effects of shallow groundwater and deficit irrigation on irrigation water productivity in arid region: New conceptual model. Science of The Total Environment, 2018; 619-620: 1170-1182.

[3] Jiang J, Huo Z L, Feng S Y, Zhang C B. Effect of irrigation amount and water salinity on water consumption and water productivity of spring wheat in northwest China. Field Crops Research, 2012; 137: 78-88.

[4] Chang X X, Zhao W Z, Zeng F J. Crop evapotranspiration-based irrigation management during the growing season in the arid region of northwestern China. Environmental Monitoring and Assessment, 2015; 187: 699. doi: 10.1007/s10661-015-4920-9.

[5] Gu Z, Qi Z M, Ma L W, Gui DW, Xu J Z, Fang Q X, et al. Development of an irrigation scheduling software based on model predicted crop water stress. Computers and Electronics in Agriculture, 2017; 143(Supplement C): 208-21.

[6] Shen Y J, Li S, Chen Y N, Qi Y Q, Zhang S W. Estimation of regional irrigation water requirement and water supply risk in the arid region of Northwestern China 1989-2010. Agricultural Water Management, 2013; 128(Supplement C): 55-64.

[7] Li S B, Zhao W Z. Satellite-based actual evapotranspiration estimation in the middle reach of the Heihe River Basin using the SEBAL method. Hydrological Processes, 2010; 24: 3337-3344.

[8] Li W, Li Y P, Li C H, Huang G H. An inexact two-stage water management model for planning cultural irrigation under uncertainty. Agricultural Water Management, 2010; 97(11): 1905-1914.

[9] Gui D W, Xue J, Liu Y, Lei J Q, Zeng F J. Should oasification be ignored when examining desertification in Northwest China? Solid Earth Discuss, 2017: under review.

[10] Xue J, Gui D W, Zhao Y, Lei J Q, Zeng F J, Feng X L, et al. A decision-making framework to model environmental flow requirements in oasis areas using Bayesian networks. Journal of Hydrology, 2016; 540(Supplement C): 1209-1222.

[11] Kang S Z, Su X L, Tong L, Zhang J H, Zhang L, Davies W J. A warning from an ancient oasis: intensive human activities are leading to potential ecological and social catastrophe. International Journal of Sustainable Development and World Ecology, 2008; 15(5): 440-447.

[12] Ye Z X, Chen Y N, Li W H. Ecological water demand of natural vegetation in the lower Tarim River. Journal of Geographical Sciences, 2010; 20(2): 261-272. 
[13] Chen Y N, Li B F, Li Z, Li W H. Water resource formation and conversion and water security in arid region of Northwest China. Journal of Geographical Sciences, 2016; 26(7): 939-952.

[14] Yu Y, Yu R D, Chen X, Yu G A, Gan M, Disse M. Agricultural water allocation strategies along the oasis of Tarim River in Northwest China. Agricultural Water Management, 2017; 187(Supplement C): 24-36.

[15] Dağdelen N, Yılmaz E, Sezgin F, Gürbüz T. Water-yield relation and water use efficiency of cotton(Gossypium hirsutum L.) and second crop corn (Zea mays L.) in western Turkey. Agricultural Water Management, 2006; 82: 63-85.

[16] Singh S K, Badgujar G B, Reddy V R, Fleisher D H, Timlin D J. Effect of Phosphorus nutrition on growth and physiology of cotton under ambient and elevated carbon dioxide. Journal of Agronomy and Crop Science, 2013; 199: 436-48.

[17] Constable G A, Bange M P. The yield potential of cotton (Gossypium hirsutum L.). Field Crops Research, 2015; 182: 98-106.

[18] Feng L, Dai J L, Tian L W, Zhang H J, Li W J, Dong H Z. Review of the technology for high-yielding and efficient cotton cultivation in the northwest inland cotton-growing region of China. Field Crops Research, 2017; 208: 18-26.

[19] Falkenberg N R, Piccinni G, Tom Cothern J, Leskovar D I, Rush C M. Remote sensing of biotic and abiotic stress for irrigation management of cotton. Agricultural Water Management, 2007; 87: 23-31.

[20] DeTar W R. Yield and growth characteristics for cotton under various irrigation regimes in sandy soil. Agricultural Water Management, 2008; 95: 69-76.

[21] Yang C J, Luo Y, Sun L, Wu N. Effect of deficit irrigation on the growth, water use characteristics and yield of cotton in arid Northwest China. Pedosphere, 2015; 25: 910-924.

[22] Shareef M, Zeng F J, Gui D W, Waqas M, Zhang B, Fiaz M. Drought Induced Interactive Changes in Physiological and Biochemical Attributes of Cotton (Gossypium hirsutum L.). International Journal of Agricultural \& Biology, 2018; 20: 539-546.

[23] Feike T, Mamitimin Y, Li L, Doluschitz R. Development of agricultural land and water use and its driving forces along the Aksu and Tarim River, P. R. China. Environmental Earth Sciences, 2015; 73: 517-531.

[24] Feike T, Khor Y L, Mamitimin Y, Ha N, Li L, Abdusalih N, et al. Determinants of cotton farmers' irrigation water management in arid Northwestern China. Agricultural Water Management, 2017; 187: 1-10.

[25] ang L S, Li Y, Zhang H Y. Partitial rootzone irrigation increases water use efficiency, maintains yield and enhances economic profit of cotton in arid area. Agricultural Water Management, 2010; 97: 1527-1533.

[26] Wang R S, Wan S Q, Kang Y H, Dou C Y. Assessment of secondary soil salinity prevention and economic benefit under different drip line placement and irrigation regime in northwest China. Agricultural Water Management, 2014; 131: 41-49.

[27] Mao D L, Lei J Q, Zhao Y, Zhao J P, Zeng F J, Xue J. Effects of variability in landscape types on the microclimate across a desert-oasis region on the southern margins of the Tarim Basin, China. Arid Land Research and Management, 2016; 30: 89-104.

[28] Zhou H, Zhang M, Zhou Q, Sun Z, Chen J. Analysis of agricultural irrigation water using coefficient in Xinjiang arid region. Transactions of the CSAE, 2013; 29: 100-107. (in Chinese)

[29] Liu C, Qi Z M, Gu Z, Gui D W, Zeng F J. Optimizing irrigation rates for cotton production in an extremely arid area using RZWQM2 simulated water stress. Transactions of the ASABE, 2017; 60: 2041-2052.

[30] Fereres E, Soriano M A. Deficit irrigation for reducing agricultural water use. Journal of Experimental Botany, 2007; 58(2): 147-159.

[31] Singh Y, Rao S S, Regar P L. Deficit irrigation and nitrogen effects on seed cotton yield, water productivity and yield response factor in shallow soils of semi-arid environment. Agricultural Water Management, 2010; 97: 965-970.

[32] Kifle M, Gebretsadikan T G. Yield and water use efficiency of furrow irrigated potato under regulated deficit irrigation, Atsibi-Wemberta, North Ethiopia. Agricultural Water Management, 2016; 170: 133-139.

[33] Ünlü M, Rıza K, Levent K D, Servet T, Burçak K. Effects of deficit irrigation on the yield and yield components of drip irrigated cotton in a mediterranean environment. Agricultural Water Management, 2011; 98: 597-605.

[34] Sampathkumar T, Pandian B J, Rngaswamy M V, Manickasundaram P, Jeyakumar P. Influence of deficit irrigation on growth, yield and yield parameters of cotton-maize cropping sequence. Agricultural Water Management, 2013; 130: 90-102.
[35] Zhang D M, Zhen L, Liu S H, Li W J, Tang W, Dong H Z. Effects of deficit irrigation and plant density on the growth, yield and fiber quality of irrigated cotton. Field Crops Research, 2016; 197: 1-9.

[36] Mamitimin Y, Feike T, Seifert I; Doluschitz R. Irrigation in the Tarim Basin, China: farmers' response to changes in water pricing practices. Environmental Earth Sciences, 2015; 73: 559-569.

[37] Rao S S, Singh Tanwar S P, Regar P L. Effect of deficit irrigation, phosphorous inoculation and cycocel spray on root growth, seed cotton yield and water productivity of drip irrigated cotton in arid environment. Agricultural Water Management, 2016; 169: 14-25.

[38] Badr M A, El-Tohamy W A, Zaghloul A M. Yield and water use efficiency of potato grown under different irrigation and nitrogen levels in an arid region. Agricultural Water Management, 2012; 110: 9-15.

[39] Hunsaker D J, French A N, Waller P M, Bautista E, Thorp K R, Bronson K $\mathrm{F}$, et al. Comparison of traditional and ET-based irrigation scheduling of surface-irrigated cotton in the arid southwestern USA. Agricultural Water Management, 2015; 159: 209-224.

[40] Xue J Y, Guan H D, Huo Z L, Wang F X, Huang G H, Boll J. Water saving practices enhance regional efficiency of water consumption and water productivity in an arid agricultural area with shallow groundwater. Agricultural Water Management, 2017; 194: 78-89.

[41] Evett S R, Schwartz R C, Casanova J J, Heng H K. Soil water sensing for water balance, ET and WUE. Agricultural Water Management, 2012; 104 $1-9$

[42] Allen R G, Clemmens A J, Burt C M. Prediction accuracy for project-wide evapotranspiration using crop coefficients and reference evapotranspiration. Journal of Irrigation and Drainage Engineering, 2005; 131(1): 24-36.

[43] Zeng F J, Bleby T M, Landman P A, Adams M A, Arndt S K. Water and nutrient dynamics in surface roots and soils are not modified by short-term flooding of phreatophytic plants in a hyperarid desert. Plant and Soil, 2006; 279: 129-139.

[44] Li H F, Zeng F J, Gui D W, Lei J Q. Characteristics of soil environment variation in oasis-desert ecotone in the process of oasis growth. In: Li D L, Liu Y, Chen Y (Ed.). Computer and Computing Technologies in Agriculture IV; Springer:.Berlin, Germany, 2011; pp. 321-334.

[45] Ishiyama T, Saito N, Fujikawa S, Ohkawa K, Tanaka S. Ground surface conditions of oases around the Taklimakan Desert. Advances in Space Research, 2007; 39(1): 46-51.

[46] Allen R G, Pereira L S, Raes D, Smith M. Crop evapotranspiration: guidelines for computing crop water requirements. FAO Irrigation and Drainage, Paper 56, FAO, Rome, 1998.

[47] Walter I A, Allen R G, Elliott R L, Howell T A, Itenfisu D, Jensen M E, et al. The ASCE standardized reference evapotranspiration equation. Am. Soc. Civil Eng., Reston, VA, 2005.

[48] Malek E. Comparison of alternative methods for estimating ETp and evaluation of advection in the Bajgah area, Iran. Agricultural and Forest Meteorology, 1987; 39: 185-192.

[49] Ögren E, Evans J R. Photosynthetic light-response curves I. The influence of $\mathrm{CO}_{2}$ partial pressure and leaf inversion. Planta, 1993; 189: 182-190.

[50] Ferreira M I. Stress coefficients for soil water balance combined with water stress indicators for irrigation scheduling of woody crops. Horticulturae, 2017; 3: 38 .

[51] Su P X, Cheng G D, Yan Q D, Liu X M. Photosynthetic regulation of C4 desert plant Haloxylon ammodendron under drought stress. Plant Growth Regulation, 2007; 51: 139-147.

[52] Wang C Y, Akihiro I, Li M S, Wang D L. Growth and eco-physiological performance of cotton under water stress conditions. Agricultural Sciences in China, 2007; 6(8): 949-955.

[53] Oweis T Y, Farahanib H J, Hachumc A Y. Evapotranspiration and water use of full and deficit irrigated cotton in the Mediterranean environment in northern Syria. Agricultural Water Management, 2011; 98: 1239-1248 .

[54] Yazar A, Sezen S M, Sesveren S. LEPA and trickle irrigation of cotton in the Southeast Anatolia Project (GAP) area in Turkey. Agricultural Water Management, 2002; 54: 189-203.

[55] Fan Y, Wang C G, Nan Z B. Determining water use efficiency of wheat and cotton: A meta-regression analysis. Agricultural Water Management, 2018; 199: 48-60.

[56] Qiu G Y, Wang L M, He X H, Zhang X Y, Chen S Y, Chen J, et al Water use efficiency and evapotranspiration of winter wheat and its response to irrigation regime in the north China plain. Agricultural and Forest Meteorology, 2008; 148: 1848-1859. 